\title{
A NEW SPECIES AND A NEW RECORD IN TRICHOSALPINX (ORCHIDACEAE: PLEUROTHALLIDINAE) FROM PERU
}

\author{
Lisa ThOERLE ${ }^{1,3} \&$ CARMEN SOTO ${ }^{2}$ \\ ${ }^{1} 23$ John Dyer Rd, Little Compton, Rhode Island, U.S.A. \\ ${ }^{2}$ Inka Terra Association - ITA, Machu Picchu, Cusco, Peru \\ ${ }^{3}$ Corresponding author: 1thoerle@cox.net
}

\begin{abstract}
A new species in Trichosalpinx is described, illustrated, and compared with similar species, and a new record for Peru is described and illustrated. A brief history of the genus is provided. Trichosalpinx reticulata is most similar to T. carmeniae, but differs with a reticulated, gray-green leaf; a longer inflorescence; and a lip with a pair of low, rounded basal lobes and an obtuse apex. Trichosalpinx acremona is recorded from Peruvian collections.
\end{abstract}

KeY wORDS: Trichosalpinx, Pleurothallidinae, Peru, taxonomy

In 1983, Luer proposed the genus Trichosalpinx to unite 85 species mostly scattered between various sections and subsections of the genus Pleurothallis R. Br., but the first species destined for this genus was discovered 181 years earlier. During their epic collecting expedition in the Americas around the dawn of the nineteenth century, Humboldt and Bonpland collected a plant in 1802 that Kunth later described as Dendrobium pusillum (Humboldt et al. 1816), now Trichosalpinx pusilla (Kunth) Luer. In the notes accompanying the original description in 1816, Kunth wondered if it might not better be described in the genus Masdevallia Ruiz \& Pav., but allowed the difficulty of examining such a small flower, coupled with the small number of specimens, to dissuade him. Before the century was out, Lindley transferred this taxon first to Specklinia Lindl. (1835) and then to Pleurothallis (1842). The confusion was not limited to this species: Lindley described the species currently known as T. ciliaris (Lindl.) Luer and T. orbicularis (Lindl.) Luer in the genus Specklinia in 1838, and the present day T. arbuscula (Lindl.) Luer and T. intricata (Lindl.) Luer in the genus Pleurothallis several years later (Lindley 1842, 1846). Subsequent species described and transferred by many others were attributed to Pleurothallis, Lepanthes Sw., Physosiphon Lindl., and Humboltia Ruiz \& Pav.

Not all of Luer's original 85 species remained in the genus Trichosalpinx, some having been transferred yet again to other genera, but new discoveries had boosted the number of species to 97 when Luer revised the genus and sorted the species between four subgenera in 1997. Luer differentiated species of Trichosalpinx from the three other genera in the Pleurothallidinae characterized by ramicauls with lepanthiform sheaths (Lepanthes Sw., Lepanthopsis Ames, and Draconanthes Luer) by the column, with four variations accepted in Trichosalpinx. Subgenus Tubella Luer, which includes the proposed species $T$. reticulata Thoerle \& C. Soto and the newly reported T. acremona (Luer) Luer, is characterized by a slender column with a column-foot and an unhooded but more or less winged apex, as well as slender ramicauls, often proliferating; racemes usually longer than the leaf; and flowers with lateral sepals nearly free from one another, entire petals, and an eciliate lip lacking basal lobules. Current investigations at the Jardín Botánico Lankester show that Trichosalpinx sensu Luer and subsequent rearrangements (Archila 2000) are not monophyletic, and generic-level changes are expected (Fernández 2013; Fernández \& Bogarín 2013; Fernández \& Karremans pers. comm. 2014).

Since 1997, the discovery of new species has resulted in a total of about 112 species accepted in Trichosalpinx (Luer 1998, 2002, 2006, 2007, 2009; Fernández-Concha \& Ramírez 1998; Archila 2000; Christenson 2001; Fernández \& Bogarín 2011, 2013). Approximately 15 species in subgenus Tubella have been identified in Peru. About an equal number of described species in the subgenus are known from very close to the borders of Peru and may be expected to occur there. 

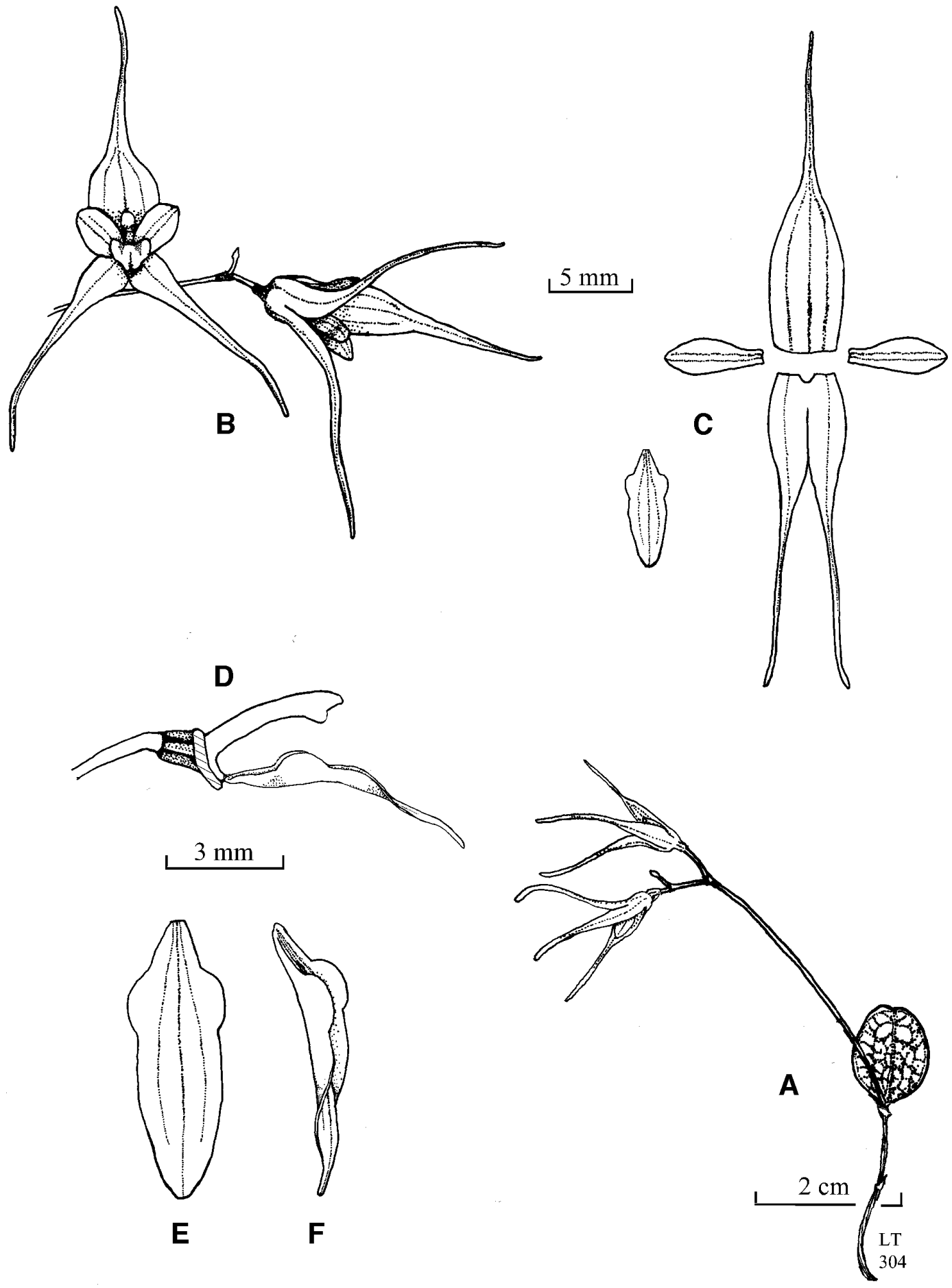

FiguRe 1. Trichosalpinx reticulata Thoerle \& C.Soto. A. Habit. B. Detail of the inflorescence. C. Dissected perianth, expanded. D. Ovary, lip, and column, lateral view. E. Lip, expanded. F. Lip, oblique view. Drawn by L. Thoerle from C. Soto Trichosalpinx \#3 (isotype: MO). 


\section{Trichosalpinx reticulata Thoerle \& C.Soto, sp. nov.}

TYPE: Peru. Cusco, on the side of a mountain within the Historic Sanctuary of Machu Picchu, $2200 \mathrm{~m}$, 24 April 2012, collected by Daniel Auccayllo et al., flowered in cultivation at the Inkaterra Machu Picchu Pueblo Hotel April 2013, C. Soto Trichosalpinx \#3 (holotype: USM!; isotype: MO!). Figs. 1, 2.

Diagnosis: This species is similar to Trichosalpinx carmeniae Luer, but differs in having gray-green, reticulated leaves, and a much longer inflorescence bearing flowers with a lip with a pair of low, rounded basal lobes and an obtuse apex.

Plant small, epiphytic, caespitose. Roots slender. Ramicauls erect to suberect, slender, $2-3 \mathrm{~cm}$ long, enclosed by 2-3 tight, ribbed, microscopically scabrous lepanthiform sheaths with dilated, acuminate ostia. Leaf coriaceous, gray-green with purple reticulation, broadly elliptical to subcircular, apex rounded and minutely retuse with a small, deflexed apiculum, 11$12 \mathrm{~mm}$ long, 9-10 $\mathrm{mm}$ wide, the broadly cuneate base abruptly contracted into a petiole $3 \mathrm{~mm}$ long. Inflorescence from the apex of the ramicaul, a loose, simultaneously few-flowered raceme of 2-4 flowers with the dorsal sepal closest to the rachis, displaying the exterior of the lateral sepals in the natural arrangement, at least $6-7 \mathrm{~cm}$ long including the erect to suberect peduncle $4-5 \mathrm{~cm}$ long. Floral bracts microscopically verrucose, acuminate, $1.5 \mathrm{~mm}$ long. Pedicels $6 \mathrm{~mm}$ long. Ovary $1 \mathrm{~mm}$ long, sulcate. Flowers light tanyellow with veins marked with red. Sepals glabrous, membranous. Dorsal sepal oblong, concave at the base, $20 \mathrm{~mm}$ long with a blade $11 \mathrm{~mm}$ long, $5 \mathrm{~mm}$ wide, 3 -veined, acute, acuminate into a slender tail $9 \mathrm{~mm}$ long, connate to the lateral sepals for $1 \mathrm{~mm}$. Lateral sepals narrowly oblong, $20 \mathrm{~mm}$ long with a blade 9 $\mathrm{mm}$ long, $2.5 \mathrm{~mm}$ wide, 1-veined, connate $2 \mathrm{~mm}$, the apices acute, acuminate into slender tails $11 \mathrm{~mm}$ long. Petals glabrous, obovate, apex obtuse, 5.5-6 mm long, $2 \mathrm{~mm}$ wide, 2-veined. Lip glabrous, elliptical, apex obtuse, $7 \mathrm{~mm}$ long, $3 \mathrm{~mm}$ wide expanded, 3-veined, the margins erect below the middle with low, rounded side lobes, the broadly cuneate base hinged to the tip of the column-foot. Column slender, with small, obtuse, rounded apical wings, 3-3.5 mm long, column-foot $0.5 \mathrm{~mm}$ long. Anther and stigma ventral. Pollinia not observed.

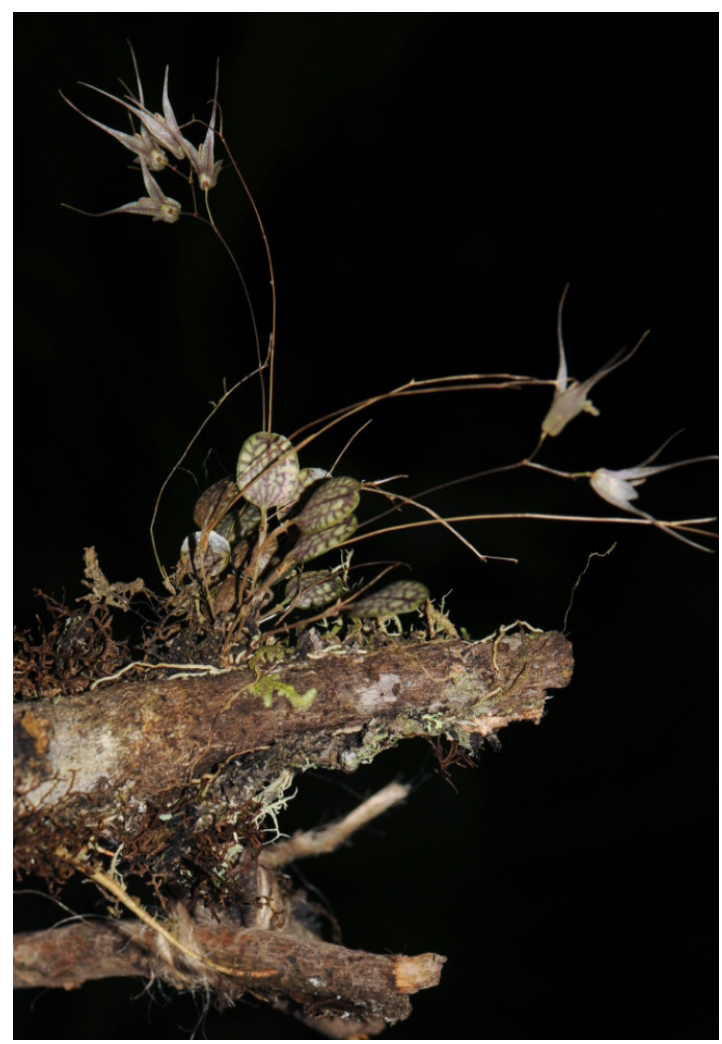

FIGURE 2. Trichosalpinx reticulata Thoerle \& C.Soto. The plant from which the type specimens were harvested. Photograph by C. Soto.

Distribution: Known only from the Historic Sanctuary of Machu Picchu, Peru.

Eтymology: From the Latin reticulatus, "netted," for the netlike pattern on the leaves.

Habitat in Peru: It grows epiphytically on small trees of Lauraceae, nestled in moss and lichens, approximately two meters above the ground, in wet cloud forest at an elevation of $2200 \mathrm{~m}$.

Phenology: Cultivated along Inkaterra's orchid trail, this species flowers in January, February, and April.

Trichosalpinx reticulata is most similar to the recently described $T$. carmeniae Luer (fig. 3, 4). The leaves of $T$. reticulata are smaller, proportionally wider (index ca. 1.2), and gray-green in color, reticulated with purple; those of $T$. carmeniae are longer, proportionally more slender, 15-16 $\mathrm{mm}$ long and about $8 \mathrm{~mm}$ wide (index $c a$. 1.9), and green without the attractive reticulation. The inflorescence of $T$. reticulata is about 


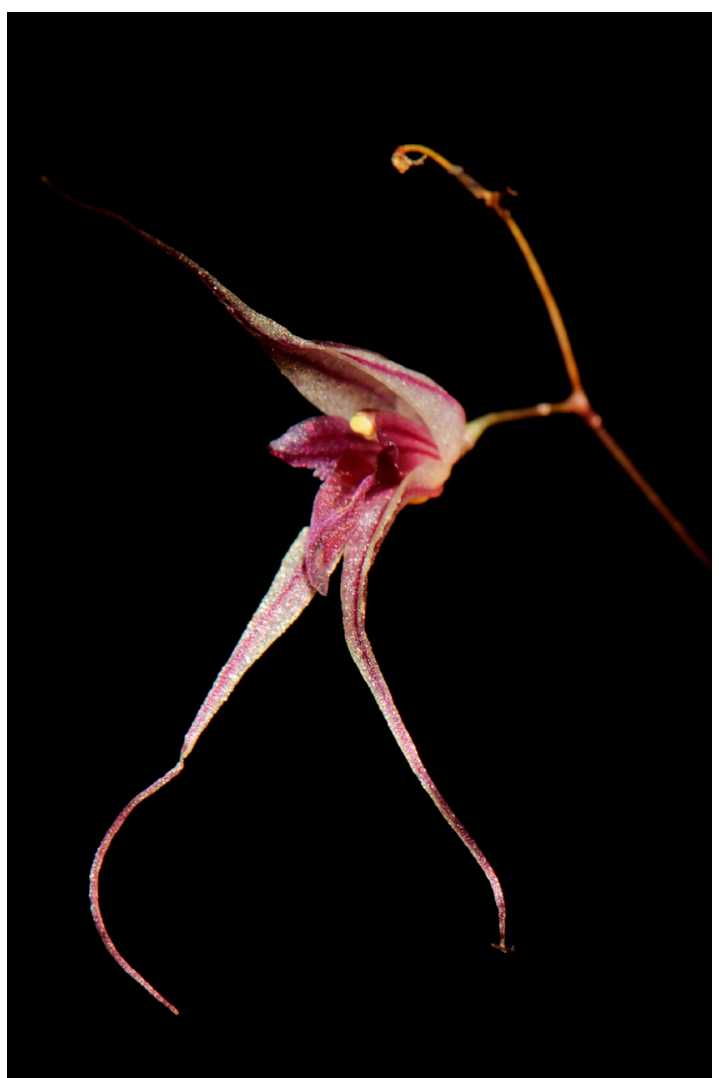

Figure 3. Trichosalpinx carmeniae. A flower of the plant from which the type specimens were harvested. Photograph by C. Soto.

thrice as long as that of $T$. carmeniae. The long-tailed, acuminate sepals and the relatively large, two-veined petals are similar in size and shape. The petals and lip of $T$. carmeniae are solid rose in color, while those of T. reticulata are tan-yellow with red veins. The pair of low, well-defined, rounded lobes on the erect margins of the basal third of the lip of $T$. reticulata differs from the obscurely 4-lobed basal half of the lip in T. carmeniae. The apex of the lip of T. carmeniae is acute, rather than obtuse.

The Inka Terra Association Team discovered this lovely species on the mist-swept side of a mountain within the Historic Sanctuary of Machu Picchu. It grows on thin branches of a small tree in the Lauraceae, nestled in moss and lichens, approximately two meters above the ground. In cultivation along Inkaterra's orchid trail, Trichosalpinx reticulata flowers in January, February, and April.

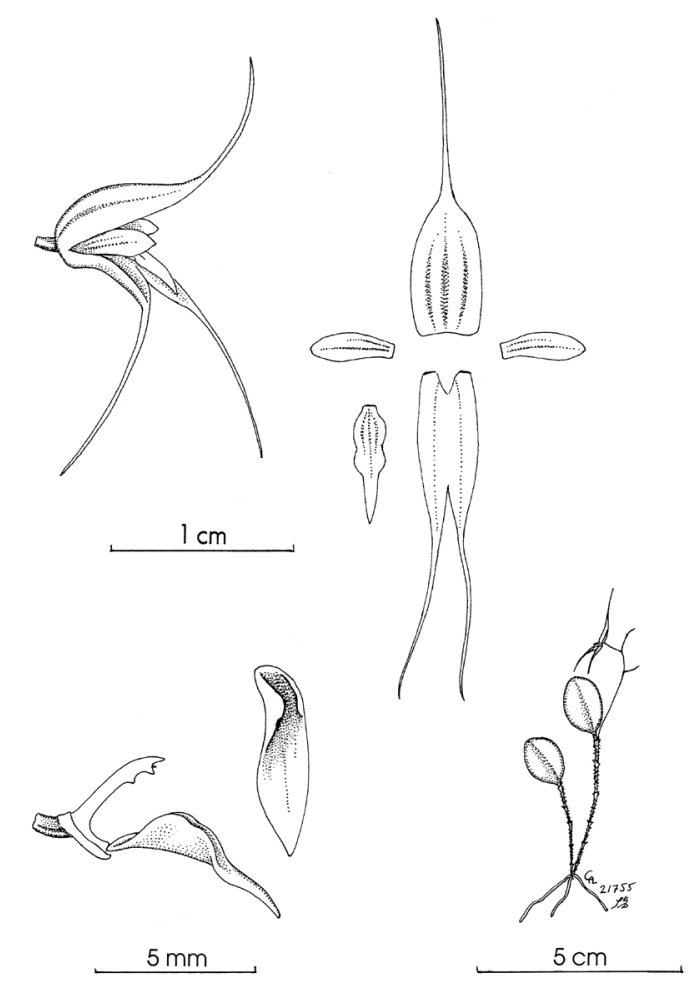

FIgURE 4. Trichosalpinx carmeniae. A. Habit. B. Flower. C. Dissected perianth, expanded. D. Ovary, lip, and column, lateral view. E. Lip, oblique view. Drawing by C. A. Luer from C. Soto Trichosalpinx \#1 (MO). Reproduced with the permission of C. A. Luer and the Orchid Herbarium of Oakes Ames, Harvard University Herbaria..

Trichosalpinx acremona (Luer) Luer, Phytologia 54: 394. 1983.

TYPE: Ecuador. Collected by Janet Kuhn, without locality, flowered in cultivation by J \& L Orchids, Easton, Connecticut, USA, November 1975, C. Luer 596 (holotype: SEL). Fig. 5.

Distribution: Colombia, Ecuador, Peru, Bolivia.

Etymology: From the Greek acremon, "a branch," referring to the branching habit of the plant.

Habitat in Peru: Epiphytic in wet cloud forest in the Historic Sanctuary of Machu Picchu between 2200 and $2600 \mathrm{~m}$ elevation.

Phenology: In cultivation along Inkaterra's orchid trail, this species flowers in March and April.

Peruvian Material Studied: Cusco: Montaña Poques, 


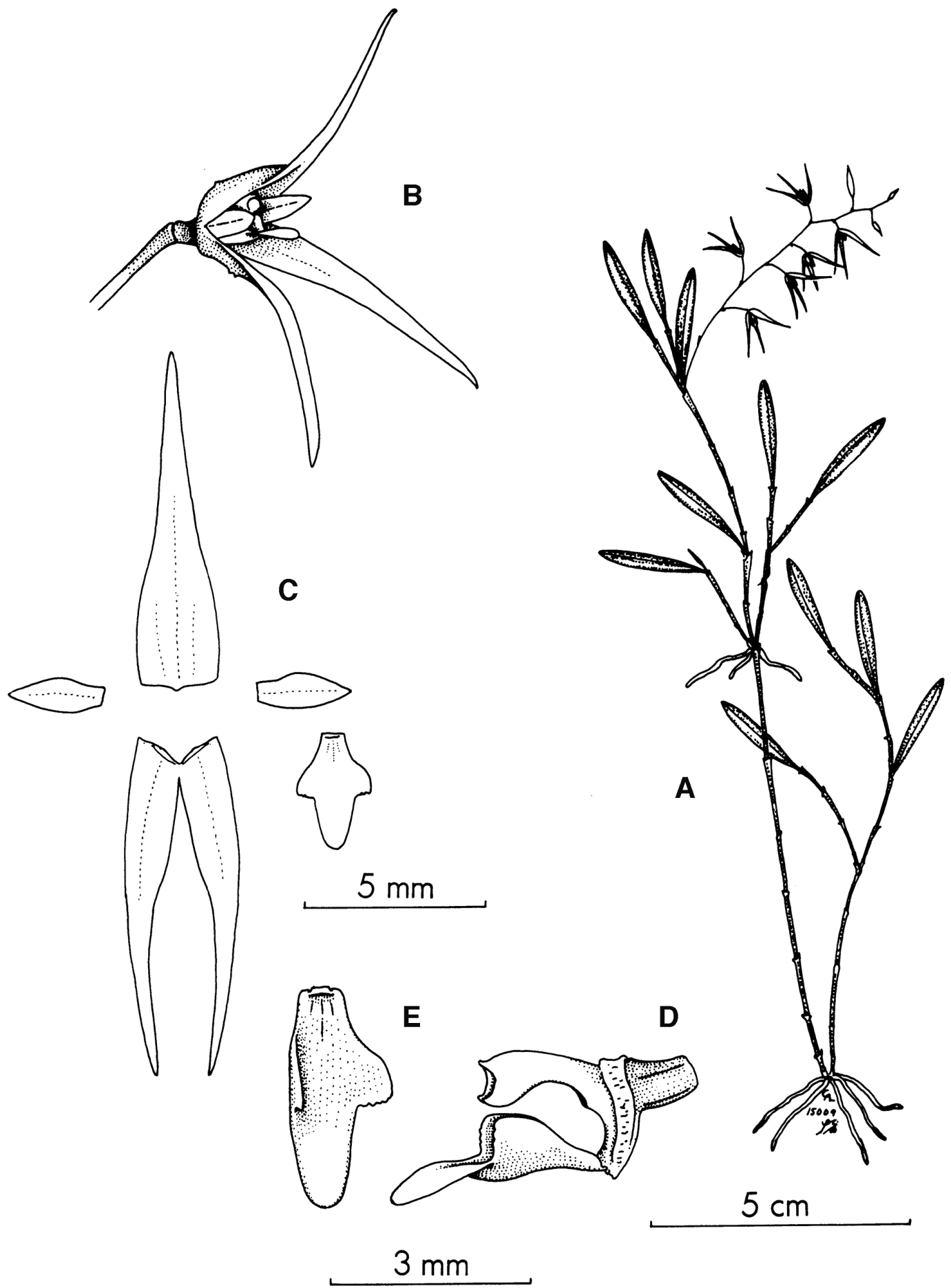

Figure 5. Trichosalpinx acremona. A. Habit. B. Flower. C. Dissected perianth, expanded. D. Ovary, lip, and column, lateral view. E. Lip, right side expanded. Drawing by C. A. Luer from C. Luer et al. 15009 (MO). Reproduced with the permission of C. A. Luer and the Missouri Botanical Garden Press. 


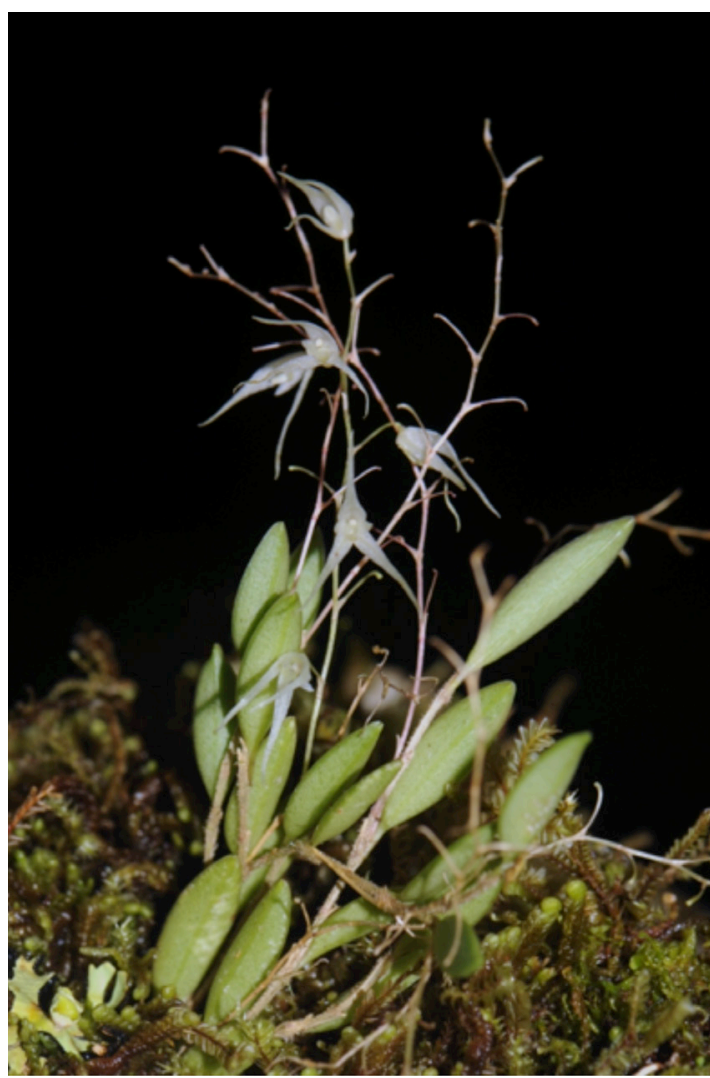

FIGURE 6. Trichosalpinx acremona. The plant from which the type specimen was harvested (C. Soto Trichosalpinx \#7, MO). Photograph by C. Soto

within the Historic Sanctuary of Machu Picchu, $2200 \mathrm{~m}$ elevation, 24 April 2012, collected by Daniel Auccayllo et al., flowered in cultivation at the Inkaterra Machu Picchu Pueblo Hotel April 2013, C. Soto Trichosalpinx \#4 (USM!, MO!). Same area, 2600 m elevation, 24 April 2012, collected by Daniel Auccayllo et al., flowered in cultivation at the Inkaterra Machu Picchu Pueblo Hotel April 2013, C. Soto Trichosalpinx \#7 (MO!). Fig. 6.

Trichosalpinx acremona has long been suspected to occur in Peru, because existing collections are known from the eastern slopes of the Andes in the surrounding countries of Colombia and Ecuador to the north, and Bolivia to the south (Luer 1997). The two specimens cited here were collected within the Historic Sanctuary of Machu Picchu by the Inka Terra Association team.

Trichosalpinx acremona (figure 5) shares a prolific growth habit, with subsequent ramicauls arising from the apex of older ramicauls, and flowers with long, slender, acuminate sepals with a number of species in the subgenus Tubella. From these similar species, $T$. acremona is most easily distinguished by the lip. The well-developed, erect lateral lobes on the basal half of the lip are distinctively antrorse with an anterior margin ranging from irregular to minutely erose. The rounded apical portion is thickened and cellular-glandular to minutely verrucose above a smooth, featureless disc.

ACKNOWLEDGMENTS. The authors thank the National Service of Natural Protected Areas (SERNANP) for the permits under which these specimens were collected and the duplicates sent to the United States; Carlyle A. Luer for permission to use his drawings, and so much more; José Koechlin of Inkaterra and José Purisaca of the Inka Terra Association-ITA for their support of research and conservation, including this project; the Orchid Herbarium of Oakes Ames, Harvard University Herbaria, for allowing us to reprint Luer's drawing of Trichosalpinx carmeniae, and the Missouri Botanical Garden Press for permission to reprint his drawing of $T$. acremona; the librarians at the Harvard Botany Library for sharing essential references; Melania Fernández and Adam Karremans for discussions of their current research on the genus Trichosalpinx; and two anonymous reviewers.

\section{Literature Cited}

Archila, F. (2000). Estudio taxonómico - morfológico y delimitación de tres géneros de la subtribu Pleurothallidinae (Orchidaceae). Revista Guatemal., 3, 33-88.

Bennett, D. E. \& Christenson, E. A. (2001). Icones Orchidacearum Peruviarum: plates 601-800. A. Pastorelli de Bennett, Lima, t. 792-793.

Fernández, M. (2013). Tubella - die etwas anderen Trichosalpinx. Die Orchidee, 64(4), 310-317.

Fernández, M. \& Bogarín, D. (2011). A new Trichosalpinx (Orchidaceae: Pleurothallidinae) from the northern Pacific lowlands of Costa Rica. Phytotaxa, 38, 41-48.

Fernández, M. \& Bogarín, D. (2013). A new species of Trichosalpinx (Orchidaceae: Pleurothallidinae) from Costa Rica. Brittonia, 65(1), 96-101.

Fernández-Concha, G. C. \& Ramírez, I. (1998). Notes on the orchid flora of the Cruz Carrillo National Park (Guaramacal), Venezuela. Harvard Pap. Bot., 3(2), 239-252. 
Humboldt, A., Bonpland, A. \& Kunth, C. S. (1816.) Nova Genera et Species Plantarum (quarto ed.) 1, 357. Paris. Hurka, H. and B. Neuffer.

Lindley, J. (1835). Pleurothallis grobyi. Edwards's Bot. Reg. 21, sub t. 1797.

Lindley, J. (1838). Specklinia ciliaris. Edwards's Bot. Reg. 24, Misc. 31.

Lindley, J. (1842). Pleurothallis. Edwards's Bot. Reg. 28, Misc. 72, 82-83.

Lindley, J. (1846). Orchidaceae Lindenianae 1, 1-38. Bradbury and Evans, London.

Luer, C. A. (1983). Trichosalpinx, a new genus in the Pleurothallidinae. Phytologia, 54(5), 393-398.

Luer, C. A. (1997). Systematics of Trichosalpinx. Monogr. Syst. Bot. Missouri Bot. Gard. 64, 1-118.
Luer, C.A. (1998). Corrigenda to Icones Pleurothallidinarum -15. Monogr. Syst. Bot. Missouri Bot. Gard. 65, 82.

Luer, C. A. (2002). Addenda to Barbosella, Dracula, Dresslerella, Lepanthopsis, Platystele, Pleurothallis, Restrepia, Scaphosepalum, Teagueia and Trichosalpinx. Monogr. Syst. Bot. Missouri Bot. Gard. 88, 97-122.

Luer, C. A. (2006). Miscellaneous new taxa in the Pleurothallidinae. Monogr. Syst. Bot. Missouri Bot. Gard. 105, 245-259.

Luer, C. A. (2007). Miscellaneous new genera, new species and new combinations. Monogr. Syst. Bot. Missouri Bot. Gard. 112, 106-114.

Luer, C. A. (2009). Miscellaneous new species in the Pleurothallidinae. Selbyana 30, 1-71. 